\title{
Green Taxes in a Federal Context: An Empirical Model for Industrial Waste in Spain
}

\author{
Jaime Vallés-Giménez, Anabel Zárate-Marco, and Carmen Trueba-Cortés ${ }^{+}$
}

\begin{abstract}
This paper reveals that the design of the green taxes levied on the production of industrial waste by certain regional governments in Spain does not appear to reduce environmental damage. This may be because these taxes try to mitigate financial shortfalls, tax rates are too low and are fixed arbitrarily, and agents react to tax differentials across regions by disposing of their waste in regions with lower or null tax rates or illegally dumping it. This suggests that the environmental issues related to the disposal of industrial waste should be supervised by the national government or somehow coordinated across regions.
\end{abstract}

Keywords: Industrial waste, green taxes, tax decentralization

JEL Classifications: $H 23, H 71$

\section{INTRODUCTION}

For some years, the production of waste of all kinds has increased sharply worldwide. Due to associated environmental problems, the high levels achieved have forced governments to take action to control and reduce such waste. ${ }^{1}$ In this context, the European Union has issued a series of guidelines, priorities, and criteria in the Framework Directive on Waste (Directive 75/442/EEC, as amended by Directives 91/156/EEC and 96/350/EC). They require member States to foster the development of clean technologies, to extract value from waste by reuse and recycling, and to use remaining rubbish as an energy source inasmuch as possible. Among the possible measures to attain these objectives, the European Commission has urged member states to use fiscal instruments to reinforce the effectiveness of their environmental policies, in particular by levying charges on activities that pollute.

Meanwhile, the option of green taxes is particularly interesting in a European context where stable budget requirements require strict limits on deficits (Stability and Growth Pact approved at the Amsterdam Council in June 1997). Spain makes a particularly interesting case to study since it requires its subregions to balance their budgets (Spanish General Budgetary Stability Act, Law 18/2001 of December 12). Fiscal instruments in an environmental context can be very helpful in budgetary terms to governments of all types. But it can be especially important below Spain's federal level, where revenue-raising powers are limited in line with the theoretical recommendations of fiscal federalism.

Whether the aim is to balance budgets or to improve environmental, research examining consequences of environmental taxes below the federal level of government is

\footnotetext{
* An earlier version of this paper was presented at the XXXIV Reunión de Estudios Regionales, held in Baeza (Spain) on November 27-28, 2008, and at the XV Encuentro de Economía Publica, held in Salamanca (Spain) on February, 5-6, 2008. The authors gratefully acknowledge the useful comments and suggestions received from the Editor and three anonymous referees of this Journal. The authors also acknowledge financial support provided by the Spanish Institute of Fiscal Studies and the Spanish Ministry of Science and Education and the European Regional Development Fund, project SEJ2007-66654. Any remaining errors are entirely our responsibility.

+ Vallés, Zárate, and Trueba are Professors of Public Economics, University of Zaragoza.

Contact author: Jaime Vallés-Giménez, Department of Public Economics, University of Zaragoza, Gran Vía 2, 50.005Zaragoza, Spain.

${ }^{1}$ See Porter (2002) for a recent analysis of the problem of waste.
} 
relevant. Two clearly differentiated patterns exist. On the one hand, a group of fairly decentralized countries tax industrial waste at the regional level. The group included Australia, Canada, Belgium, Germany, Italy, Spain, and some U.S. states. On the other, France, Austria, the United Kingdom and others tax waste centrally. The very localized nature of many environmental problems makes research on the decentralization of green taxation particular interesting. The generation of industrial waste is no exception.

The specific purpose of this study is to establish whether the green taxes levied on industrial waste by certain regional governments in Spain reduce environmental damage through the economic agents' responses. We believe the Spanish experience may shed some light on the functioning and effects of environmental taxes on industrial waste. In this way our study may provide a benchmark against which to assess the potential effects of green taxes in other countries where such taxes are managed by regions. Specifically, we seek to clarify the extent to which environmental taxation dissuades the generation of industrial waste. In a second phase we examine whether the decisions adopted by Spanish regions produce effective green tax rates that yield a sufficient disincentive to pollute. If this is not the case, we may conclude that the charges introduced by some regional governments fail in environmental terms. That is, if higher green tax rates do not curtail the generation of industrial waste, the charges fail to produce the desired environmental outcomes, even though it may comply with the polluter-pays principle. We estimate a model using the panel data techniques using variables that should shed some light on the environmental purpose of green taxes. As far as we are aware, this approach to the issue has not previously been taken. In this vein, we understand ours to be a pioneering study.

The paper is structured as follows. We first examine economic arguments concerning fiscal decentralization. We then review the taxes levied on waste in Spain, showing that only the lower (regional and local) tiers of government apply such charges and, furthermore, that the taxes are general rather than specific. In order to contextualize the situation in Spain and compare it to other countries, we briefly review the taxation of waste internationally before describing the Spanish situation in detail. We find that very few OECD countries tax waste at an intermediate spatial level, applying charges either centrally or quite locally. Still, charges for specific types of waste exist in most OECD tax systems. We go on to test whether the green taxes levied on industrial waste by certain regional governments in Spain reduce the generation of industrial waste. For this purpose, we estimate a logarithmic model for regional waste generation based on panel data and fixed effects with temporal dummies. Our results indicate that taxation at the regional level may not be appropriate as an incentive for reducing the generation of waste. The paper concludes with some final remarks.

\section{ECONOMICS OF GREEN TAXATION: CENTRALIZE OR DECENTRALIZE?}

From a theoretical standpoint, the decentralization of waste management involves three key issues. First, the need for public sector intervention to correct market failure must be justified. The environmental impacts and public health problems are undeniably negative externalities associated with the generation of waste. Moreover, unfettered market forces produce inefficient outcomes, given that enormous quantities of waste/resources, which could be reused, often are instead simply dumped.

There is no need to insist here on the second point, because it is basically a matter of selecting the right tool to implement public-sector action. Green taxes form a part of the traditional theoretical corpus of economics, given that pollution is a clear example of a negative externality and that Pigouvian taxes are a mechanism to manage such market failure. Nevertheless, governments typically have preferred command and control type regulation for 
environmental protection purposes. The continued degradation of the environment has, however, demonstrated the limitations of conventional regulation and has encouraged efforts that identify supplementary interventions. Thus attention has turned to tool grounded in economics, including corrective taxes. As a consequence, the presence of fiscal instruments as part of environmental policies has arisen only since the 1980s (see OECD 1989, 1994). Since then numerous arguments have been advanced in the literature highlighting the advantages of green taxes over conventional regulation. ${ }^{2}$

The third issue in the context of a decentralized state is identifying the level of government that is the most appropriate for managing waste and more generally, perhaps, environmental policy. This issue continues to be hotly debated. ${ }^{3}$

According to the concept of equivalence embodied in the theory of fiscal federalism, the responsibility for green taxes should be assigned to the jurisdictional level at which the costs are equal to the benefits associated with environmental goods (Olson, 1969). The optimum level of emissions would be that at which the marginal social cost caused by pollution is equal to the marginal cost of cleaning up. This suggests that any centralized governmental solutions to asymmetrical environmental problems across different regions are likely to be inefficient (Peltzman and Tideman, 1972). Of course, it would be possible to reach an efficient centralized solution by letting federal tax rates vary across jurisdictions. But the problems of information gathering and management needed to enable federally established, spatially varying rates would be considerable. Thus, environmental issues, characteristically a sub-national public good, should be regulated at an appropriate subnational tier of government.

The advantages of tax decentralization have been widely debated in the literature. A number of scholars have suggested that differences in tax rates between jurisdictions may result in destructive fiscal competition causing generalized efficiency losses (Stein, 1971; Kneese, 1971; Cumberland, 1981; Levinson, 2003; and Kunce and Shogren, 2005). The classic formulation of the argument against tax competition was put forward by Oates (1972, p. 143):

The result of tax competition may well be a tendency toward less than efficient levels of output of local services. In an attempt to keep taxes low to attract business investment, local officials may hold spending below those levels for which marginal benefits equal marginal costs, particularly for those programs that do not offer direct benefits to local business.

Authors like Oates and Schwab (1988), Shapiro and Petchey (1997), and Roelfsema (2007) have since shown that sub-national jurisdictions, under certain conditions, tend to establish tax incentives for new industries and socially optimum levels of emissions despite inter-jurisdictional competition. Thus, green tax competition does not necessarily result in higher pollution. In any case, these conclusions depend on strong assumptions in relation to technology, the size of jurisdictions, the existence of strategic behaviors, and so on, as Levinson (2003) and García-Valiñas (2005) have shown. If these are relaxed, the conclusion may be that competition between jurisdictions causes a loss of welfare (as found in studies such as Zodrow and Mieszkowski, 1986; Wilson, 1986; Wildasin, 1989; Markusen, Morey, and Olewiler, 1993, 1995; and Oates, 2002).

\footnotetext{
2 See, e.g., Baumol and Oates (1988), Summer (1991), Smith (1992), Gago and Labandería (1997), Department of the Environment, Transport and the Regions (1998), and López et al. (2006).

${ }^{3}$ For a review of the pertinent literature, see Dalmazzone (2006).
} 
Moreover, the presence of public-sector failures and the pursuit of rents or votes may serve as a reminder that the actions of civil servants, politicians, and voters can be a response to private concerns, with the result that government action taken is not always in the best interest of society as a whole. This is especially important in the case of green taxes in view of their potential impacts on the economic system. In a decentralized context, moreover, these factors are even more crucial, since the decisions of sub-national governments can affect matters that are especially sensitive and may have electoral consequences. Some affected matters can even fall within the purview of national government, such as inflation, employment, growth, or the distributive impact of essential goods. Meanwhile, possible undesired effects of environmental taxation on efficiency, competition, growth, and employment may encourage sub-national governments to establish suboptimal green tax rates, ${ }^{4}$ potentially causing spill-over effects in other jurisdictions due to the effect on localization decisions and the mobility of production factors and economic agents. In both cases, such coordination problems and externalities between different tiers of government, or among jurisdictions at the same level, may distort the efficiency of the tax.

Most empirical studies find no evidence for competitive cuts in environmental taxes (Dinan, Cropper, and Portney, 1999; Fredriksson, 2000) or for significant changes in the siting of plants, trade flows, or net exports as a consequence of changes in environmental regulations (see, for example, Jaffe et al., 1995). Some studies even find the contrary effect (Millimet, 2003), which is to say a race to the top in taxation among competing jurisdictions, as predicted formally by Markusen, Morey, and Olewiler (1995) and Glazer (1999), among others. As far as we are aware, however, no empirical studies have established whether subnational green taxes succeed in reducing the pollution generated by industrial waste.

In short, theoretical and empirical arguments exist for the use of eco-taxes by subnational levels of government that have the autonomy to set the tax rate. As Kneese (1971) and Oates (2002) suggest, however, it may be desirable to define a minimum level of green taxation nationwide in order to ensure a standard for acceptable environmental quality. Of course, in this case, sub-national levels of government may set higher rates if they wish to do so. According to Gago et al. (2005), some scholars have even defended geographical variations in tax rates that would be decided and managed centrally in order to prevent strategic behaviors. ${ }^{5}$

As a step toward plugging the gaps in the comparative literature, through the applied study described in this paper we seek to discover whether green taxes on waste levied at the regional level in Spain reduces waste generation. We believe the Spanish case is particularly appropriate for the study of sub-national green taxes on waste because while the national government and the regional and local tiers of government currently have the power to tax environmental goods, moreover, the present waste management situation is clearly unsatisfactory. As Puig (2001) points out, in recent decades little tangible progress has been made in reducing the level of waste generated. Indeed, the weight, volume and toxicity of waste continue to rise yearly. The same cannot be said of recycling, however, a field in which there has been a considerable improvement. This disparity in outcomes is due to the very

\footnotetext{
${ }^{4}$ This gives rise to a public choice argument along the lines that voters of more industrial areas do not support such taxes because they prefer to protect jobs, even though these dirtier regions may warrant an even higher tax rate from the environmental point of view. However, there is another, very different, reason for this phenomenon. Less developed regions face tougher financial constraints, and they may seek to offset lower tax revenues by establishing green taxes, given that they are socially acceptable and have a smaller electoral impact.

${ }^{5}$ For example, a sub-central government could set green tax rates based on the preferences of its citizens and then transfer the revenues raised to the federal government (Smith, 1995).
} 
different logic applied to the waste reduction and recycling efforts, despite the fact that they are parallel policy strategies. While recycling creates an industry and markets and therefore is fairly well aligned with the accepted economic principles, the same cannot be said of waste reduction. Not generating waste has hardly any impact on the creation of new economic activities. Reducing waste means refraining from the production (or consumption) of numerous short-lived goods. Unfortunately, the market provides no incentive to militate against such production or the consumption of it. (Indeed, the only market incentive for cutting such waste is the savings obtained from a more efficient use of materials.) This is largely because the benefits (or the absence of costs) of cutting waste are collective rather than individual. The collective nature of the benefit accrual of waste reduction explains why waste reduction is defined as a priority objective in all governmental proposals for the management of industrial waste. Waste reduction behavior will only proliferate, therefore, if it is not only identified as a public goal but also if the necessary environmental policy instruments are provided by the government. Some Spanish regions have recently established green taxes. In many cases they are the only such instrument available specifically to affect the generation of waste since no tax exists at the national level and since municipal rubbish charges are generally fixed levies that have no effect upon the goal of waste reduction. Before considering the Spanish case in depth, however, let us first examine the situation of eco-taxes on waste at the international level.

\section{OVERVIEW OF INTERNATIONAL WASTE TAXES: THE CASE OF SPAIN}

Though we are mainly interested in the Spanish case, we believe it will be of interest to provide an overview of green taxes on industrial waste in partner countries. This information is summarized in Table 1.

Basically, there are two types of green tax; namely charges levied in general on the generation of urban or industrial waste, and charges levied specifically on different kinds of industrial waste. Given the wide range of different charges, it is not possible to draw any very general conclusions. However, we would highlight certain salient issues:

- Some kind of charge on waste (whether general or specific) is levied centrally in the majority of countries, and the rate of these taxes therefore does not vary anywhere within their territory. Only in Spain and Japan is there no central government taxation of any kind on waste.

- Only a minority of countries levies any kind of general or specific taxes on waste at the regional level. Spain is one, but it is also the only country that levies waste taxes at the regional level but not the federal level. As we shall see below, only four of the seventeen Spanish regions have established any kind of general waste tax.

- Meanwhile, service charges are widely applied at the municipal level for rubbish collection. Similar municipal charges are applied all over the world, based on pay-asyou-throw or unit pricing systems (e.g. pay-per-bag schemes requiring the use of standard bin liners; pay-per-tag schemes, in which users must tag conventional bin bags; and pay-per-can schemes, which involve payment for door-to-door collection of a private rubbish bin; as well as common bins fitted with scales and a reader for individual user cards ${ }^{6}$ ). Many municipalities, however, still apply fixed rubbish charges that may or may not cover the full cost of urban waste collection, transport, and

\footnotetext{
${ }^{6}$ For a discussion of these economic instruments, see Dinan (1993), Fullerton and Kinnanan (1995) and Taylor (2000). Puig (2001) and André and Cerdá (2006) describe the problems involved in the use of these methods.
} 


\section{TABLE 1. Environmental Taxes on Waste Products in OECD Countries*}

\begin{tabular}{|c|c|c|c|c|c|}
\hline \multirow[b]{2}{*}{ Country } & \multicolumn{3}{|c|}{ General Charges } & \multicolumn{2}{|c|}{ Specific Charges } \\
\hline & National & Regional & Local & National & Subnational \\
\hline Australia & & NH & $\mathrm{NH}$ & Oils & \\
\hline Austria & $\mathrm{NH}$ & & $\mathrm{NH}$ & $\begin{array}{l}\text { Household appliances, packaging, containers, pesticides, paper, batteries, } \\
\text { disposable cameras }\end{array}$ & \\
\hline Belgium & & $\mathrm{H} \& \mathrm{NH}$ & NH & $\begin{array}{l}\text { Paper, plastic bags, batteries, solvents, disposable cameras, containers, razor } \\
\text { blades, pesticides }\end{array}$ & \\
\hline Canada & & NH & NH & Air conditioning & $\begin{array}{l}\text { Tires, aerosols, batteries, non-returnable containers, electronic } \\
\text { devices, pesticides }\end{array}$ \\
\hline Czech Republic & $\mathrm{H} \& \mathrm{NH}$ & & NH & Scrap vehicles & \\
\hline Denmark & $\mathrm{H} \& \mathrm{NH}$ & & NH & $\begin{array}{l}\text { Tires, batteries, cables, cork, light bulbs, disposable tableware, plastic } \\
\text { packaging, cardboard, aluminum, glass, plastic bags, pesticides }\end{array}$ & \\
\hline Finland & $\mathrm{H} \& \mathrm{NH}$ & & $\mathrm{NH}$ & Abandoned vehicles, containers, transportation of oil, lubricants, pesticides & \\
\hline France & NH & & NH & Cardboard, paper and containers & \\
\hline $\begin{array}{l}\text { Germany } \\
\text { Greece }\end{array}$ & $\begin{array}{c}\mathrm{H} \& \mathrm{NH} \\
\mathrm{NH}\end{array}$ & NH & $\begin{array}{l}\mathrm{NH} \\
\mathrm{NH}\end{array}$ & & Aluminum, plastic, card used in products \\
\hline Hungary & $\mathrm{H} \& \mathrm{NH}$ & & $\mathrm{NH}$ & Batteries, refrigerators, tires, plastic containers, paper, glass, aluminum & \\
\hline Iceland & & & $\mathrm{NH}$ & Batteries, cardboard, paper, plastic bottles, glass, plastic bags & \\
\hline Ireland & & & NH & Plastic bags, pesticides & \\
\hline $\begin{array}{l}\text { Italy } \\
\text { Japan }\end{array}$ & & $\mathrm{H} \& \mathrm{NH}$ & $\begin{array}{l}\mathrm{NH} \\
\mathrm{NH}\end{array}$ & Plastic bags, lubricants, pesticides & \\
\hline Korea & & & $\mathrm{NH}$ & $\begin{array}{l}\text { Cigarettes, chewing-gum, electrical devices, containers, insecticides, } \\
\text { lubricants }\end{array}$ & \\
\hline Netherlands & NH & & NH & & \\
\hline Norway & NH & & $\mathrm{NH}$ & Containers, lubricants & \\
\hline $\begin{array}{l}\text { Poland } \\
\text { Portugal }\end{array}$ & $\mathrm{H} \& \mathrm{NH}$ & & $\begin{array}{l}\mathrm{NH} \\
\mathrm{NH}\end{array}$ & $\begin{array}{l}\text { Packaging/containers, plastic bags, chemicals } \\
\text { Batteries, containers, medicine packaging, tires }\end{array}$ & \\
\hline Slovakia & $\mathrm{H} \& \mathrm{NH}$ & & $\mathrm{NH}$ & Batteries, fluorescent lamps, plastics, oils, cardboard, tires, electrical devices & \\
\hline Spain & & $\mathrm{H} \& \mathrm{NH}$ & $\mathrm{NH}$ & & \\
\hline Sweden & NH & & $\mathrm{NH}$ & $\begin{array}{l}\text { Batteries, scrap vehicles, aluminum cans, electricity generated at nuclear } \\
\text { plants, drinks containers and fertilizers }\end{array}$ & \\
\hline Switzerland & $\mathrm{NH}$ & & $\mathrm{NH}$ & Vehicles, glass bottles, aluminum cans, batteries, electrical devices & \\
\hline United Kingdom & $\mathrm{H} \& \mathrm{NH}$ & & & & \\
\hline United States & $\mathrm{H} \& \mathrm{NH}$ & $\mathrm{H} \& \mathrm{NH}$ & NH & & $\begin{array}{l}\text { Tires, lubricants, batteries, generators, containers, anti-freeze, } \\
\text { organic solvents, household appliances, radioactive waste }\end{array}$ \\
\hline
\end{tabular}

Note: $* \mathrm{H}$ denotes hazardous, and $\mathrm{NH}$ nonhazardous. Source: OECD/EEA database on instruments used for environmental policy and natural resources management http://www2.oecd.org/ecoinst/queries/index.htm). 
treatment services (the purpose of these charges is therefore strictly financial, although they sometimes include environmental costs or incentives to reduce or recycle waste). This is the case in the majority of Spain's towns and cities. In some cases, the tax base for rubbish collection charges is established relative to the size of dwellings (square meters), the number of household inhabitants, and/or water consumption. In some Spanish municipalities the charges may also be linked to other levies, such as the property tax as a means of aligning the charges with the ability to pay.

- In almost all countries (except Iceland, Ireland, Japan, Korea, and Portugal), general taxes are levied by either the national or regional government. The most common form of general waste tax is the charge levied at the national government level on waste dumped or burned, and it is intended to reduce the volume of waste and foster reuse and recycling. In many countries, the national government takes into account the levels of hazard or pollution associated with waste products and their final destination, differentiating between waste disposed of at special facilities for elimination, storage or incineration, and waste dumped in unregulated or unauthorized tips. It is also common to classify waste based on source, distinguishing between waste produced by urban building and demolition and waste produced by manufacturing industry, mining and the production of aggregates and sand. Green taxes of this kind have also been introduced in some regions. In Spain, general waste taxes are levied at the regional level. Meanwhile, some regions differentiate between hazardous and nonhazardous waste and take the origin of waste and the possibility of recycling into account.

- Taxes on specific kinds of waste have become common in recent years. These charges are usually levied on the physical units of a specific industrial product, such as chemicals, plastic bags, batteries, packaging and containers, and tires. They tend to be established centrally, and so the tax rates do not vary within the same country. Charges may be applied either to end users or to manufacturers. No specific charges of this kind are levied in Spain, either at the national or regional/local levels.

Following this brief overview of the situation in the OECD, we now describe the Spanish context in more detail. Despite the inevitable peculiarities of the case, the structure of green taxes on industrial waste in Spain is similar to that found in neighboring countries and in other nations with a similar level of economic development. Specifically, Spain has opted to legislate and manage green taxes at the regional level, as is also the case in Australia, Canada, Belgium, Germany, Italy, and some U.S. States. In this light, we believe the experience of Spain's regional governments provides an example that will help us understand the functioning and implications of environmental taxation in other countries. The taxation of waste in Spain is subject to Directive 91/156/EEC of the European Council, of 18 March 1991, and the Spanish Waste Act (Law 10/1998), which transposes Directive 91/156/EEC into domestic law. Various taxes are currently levied on waste at the sub-central level pursuant to this legislation. In the sphere of local government, the Spanish Local Finance Regulation Act (Law 7/1985) allows local corporations to establish charges and fees for "urban waste collection and treatment services", taking into account the limits on their regulatory powers. Thus, the amount of the charges established must be linked to the cost of providing the municipal service (article 24.1, Local Finance Regulation Act), or it must be directly or indirectly related to the costs mitigated (i.e., the pollution caused or the upkeep of 
the resource affected). Regardless, charges may not be used to change behavior, which would require additional costs above and beyond those needed for the fulfillment of a service.

It is far from easy to measure the quantity of waste produced by each household, however. ${ }^{7}$ Moreover, in order to avoid controls and payment of the tax, some people might opt to take their waste to other districts or towns that use conventional collection systems (rubbish tourism) or, worse yet, they might dump it illegally (fly-tipping and individual burning are both widespread in Spain). ${ }^{8}$ Whether as a result of the problems inherent in these methods or simply out of inertia, a lion's share of Spanish town councils continue to use decades-old conventional systems that do not directly link rubbish collection charges to the generation of waste, passing over the opportunity to create any sought-after incentives.

If appropriate economic stimuli are to be created to reduce waste and foster recycling, it will be necessary to link the amount of the charge and the amount of waste generated. This means defining an increasing charge (by way of the green tax) and establishing a system of rebates for activities that help cut pollution (Puig, 2001). The truth is that a fixed charge per household is applied by most Spanish towns and cities. This charge is not only regressive, it is also marginally decreasing, since the payment per physical unit shrinks for any given household or businesses as it produce more rubbish. ${ }^{9}$ Contrary to conventional practice, it is not equitable for everybody to pay the same, since those who generate the least waste, in effect, subsidize those who produce the most (Field, 1995). To sum up, the current design of Spanish charges for municipal rubbish collection generates revenues that finance a municipal service but they do not take account of environmental goals in any manner. The system is also fiscally very regressive.

Three regions (Andalusia, Madrid, and Murcia) ${ }^{10}$ have established green taxes on waste $^{11}$ that are over and above any municipal service charges for waste collection and solid waste treatment. ${ }^{12}$ Table 2 shows the charges levied on the delivery of waste at public or private tips, as well as on illicit dumping at unauthorized sites pursuant to the legislation governing waste in force in each region. The taxes established by these three regions have two basic objectives: (1) to regulate (i.e. reduce) the generation of industrial waste and (2) to finance the cost of protecting the environment, although this latter is not explicitly recognized in the region of Madrid.

The definition of the taxpayer also differs in each case. Andalusia and Madrid define the taxpayer in a general manner - as any party bringing waste to a dump. Andalusia, however, also taxes parties that exceed the maximum period permitted by law for temporary dumping prior to elimination or reuse, and Madrid taxes those responsible for dumping at an

\footnotetext{
${ }^{7}$ As mentioned above, pay-as-you-throw or unit pricing systems have been tested in different places all over the world to seek a solution to this issue.

${ }^{8}$ Other possible strategies to reduce the tax charge could be to compact rubbish or use counterfeit standard bags and tags.

${ }^{9}$ Some municipalities have conducted trials with the aim of bringing the charge into line with ability to pay, basing the rate on residence (street or district), integrating it with other levies, such as Property Tax or Business Activities Tax, or linking it with the amount of water consumed.

${ }^{10}$ In 2007 the Autonomous Community of Murcia had not yet applied the tax on the storage and dumping of waste, and it has therefore not been included in our empirical analysis.

${ }^{11}$ The region of Castile-La Mancha approved a tax on certain activities affecting the environment in 2000, including, inter alia, the storage of radioactive waste. This region also taxes the production of radioactive waste. However, Spanish industrial waste statistics do not include radioactive materials and this region has therefore been excluded from the analysis.

${ }^{12}$ As mentioned above, no federal government taxes on waste exist in Spain.
} 
TABLE 2. Region Taxes on Industrial Waste in Spain

\begin{tabular}{|c|c|c|c|}
\hline $\begin{array}{l}\text { Tax } \\
\text { components }\end{array}$ & $\begin{array}{c}\text { Andalusia } \\
\text { (Hazardous Waste Dumping } \\
\text { Tax), Regional Law 18/2003, } \\
\text { of 29 December }\end{array}$ & $\begin{array}{c}\text { Madrid } \\
\text { (Waste Dumping Tax), Regional Law } \\
6 / 2003 \text {, of } 20 \text { March }\end{array}$ & $\begin{array}{c}\text { Murcia } \\
\text { (Waste Storage and Dumping Tax), } \\
\text { Regional Law 9/2005, of } 29 \\
\text { December }\end{array}$ \\
\hline $\begin{array}{l}\text { Taxable } \\
\text { actions }\end{array}$ & $\begin{array}{l}\text { - Delivery of hazardous waste } \\
\text { at public or private dumps } \\
\text { - Temporary storage of } \\
\text { hazardous waste at the } \\
\text { producer's facilities prior to } \\
\text { disposal or value extraction } \\
\text { after expiration of the } \\
\text { maximum period permitted } \\
\text { by law. }\end{array}$ & $\begin{array}{l}\text { - Delivery of waste at public or private } \\
\text { dumps. } \\
\text { - Illicit dumping at sites not authorized } \\
\text { under Madrid regional legislation } \\
\text { governing waste }\end{array}$ & $\begin{array}{l}\text { - Delivery of waste at public or } \\
\text { private dumps. } \\
\text { - Illicit dumping or tipping at sites } \\
\text { not authorized under Murcia } \\
\text { regional legislation governing waste } \\
\text { - Storage of waste for periods } \\
\text { exceeding those defined in regional } \\
\text { legislation. }\end{array}$ \\
\hline Taxpayer & $\begin{array}{l}\text { - Parties delivering waste to } \\
\text { dumps, and who may exceed } \\
\text { the maximum period } \\
\text { permitted by Law for the } \\
\text { temporary storage of waste } \\
\text { prior to elimination or value } \\
\text { extraction in the case of } \\
\text { hazardous waste. }\end{array}$ & $\begin{array}{l}\text { - Parties delivering waste to dumps, as } \\
\text { well as persons responsible for illicit } \\
\text { dumping at unauthorized sites. }\end{array}$ & - Parties that operate dumps. \\
\hline Tax base & $\begin{array}{l}\text { - Weight of hazardous waste } \\
\text { deposited, or cubic meters in } \\
\text { the case of radioactive waste. }\end{array}$ & $\begin{array}{l}\text { - Weight or volume of waste deposited } \\
\text { or dumped. }\end{array}$ & $\begin{array}{l}\text { - Weight or volume of waste } \\
\text { deposited or dumped. }\end{array}$ \\
\hline Tax rate & $\begin{array}{l}\text {-€35/ton of hazardous waste } \\
\text { suitable for value extraction. } \\
\text {-€15/ton of hazardous waste } \\
\text { unsuitable for value } \\
\text { extraction. }\end{array}$ & $\begin{array}{l}-€ 10 / \text { ton of hazardous waste } \\
-€ 7 / \text { ton of non-hazardous waste, } \\
\text { excluding construction and demolition } \\
\text { rubble. } \\
-€ 3 / \mathrm{m}^{3} \text { of rubble produced from } \\
\text { construction or demolition work. }\end{array}$ & $\begin{array}{l}-€ 30 / \text { ton of hazardous waste } \\
-€ 7 / \text { ton of non-hazardous waste and } \\
\text { non-domestic urban waste } \\
-€ 3 / \mathrm{m}^{3} \text { of rubble produced from } \\
\text { construction or demolition work. }\end{array}$ \\
\hline
\end{tabular}

authorized sites. Murcia, meanwhile, defines the taxpayer as the party licensed to operate the dump, which clearly simplifies tax management. ${ }^{13}$

The tax base refers to the weight or volume of waste brought to dumps for disposal (or dumped unlawfully in the cases of Madrid and Murcia), which is generally determined directly by weighing. The tax payable, meanwhile, is calculated by applying a series of rates to the assessment base, distinguishing basically between hazardous waste and rubble from building and demolition work, and materials suitable for reuse or recycling.

The waste taxes that have recently been introduced in some of the Spanish regions may perform a regulatory function, as any party responsible for dumping is obliged to pay; thus they may help to reduce pollution. However, there is a lack of any increasing scale of charges or change in the tax rate based on the pollution load by each type of waste or on opportunities to extract value. This all militates against the alignment of the tax liability with the environmental damage caused or with the actual cost of treatment and disposal. From this it may be inferred that green taxes on waste have been set without designs for developing incentives to cut waste generation. A basic fiscal issue is that any reduction achieved necessarily affects the amount of revenues raised. In this vein, the basic hunger of municipalities for funds to feed their coffers is at odds with the goal of environmental protection. In all likelihood, the existence of green taxes at the region level could have

\footnotetext{
${ }^{13}$ No difference between the dumping agent or dump owner is made in the public economics literature, as the eventual tax burden is the same (i.e. the classic tax incidence effect).
} 
primarily environmental purposes, but they may also serve to mitigate financial shortfalls and to enhance the autonomy, however limited, of the regional funding system via a tax that enjoys widespread social consensus

\section{AN ECONOMETRIC MODEL FOR GREEN CHARGES ON INDUSTRIAL WASTE IN SPAIN}

In this section we propose the specification of an explanatory model for the generation of industrial waste in Spain based on taxation at the level of regional government. Specifically, we seek to clarify the extent to which environmental taxation dissuades the generation of industrial waste. The finding from this work then feeds into a second aspect of research that investigates whether the green tax rates of the different Spanish regions provide sufficient disincentives for industrial pollution. If this is not the case, we can conclude that regional governments have so far failed to set these charges appropriately, as they do not meet the goals of a preventive environmental policy. Thus, if higher green tax rates do not curtail the generation of industrial waste, they fail to produce true environmental outcomes, even though they may assure that the polluter-pays principle holds with regard to ecological damage.

Among the difficulties of this research are the complexity of Spain's sub-national government structure and constraints affecting the performance of econometric time-series studies. We believe these problems can be at least partially resolved using panel data techniques, which allow for shallower-than-normal periods of study while facilitating the examination of asymmetrical behavior across regions.

We have also sought solutions to two additional problems: the heterogeneity of data and the difficulty of comparison across regions and years. On the one hand, we ensure the uniformity of information by using data from a single source, the Spanish National Statistics Institute (Instituto Nacional de Estadística or INE). In order to avoid problems with the comparison of figures over time and across regions, we express data in real terms where appropriate and, in some cases, normalized by the region's population, GDP contribution, or volume of industrial waste production.

Finally, our use of aggregate or mean values at the regional level in our econometric estimates could be a cause for concern because we eliminate the possible influence of individual behavior of economic agents by region and because we do not consider the marginal green-tax rates. A lack of disaggregated data obliged us to proceed in this manner. Furthermore, the tack we take here is commonly applied in the international literature, and the results obtained from such studies appear reasonable. This is very likely because the information available to economic agents is imperfect, especially in view of the complexity of tariffs, since the tax rates applied are not uniform. In any case, this all also means we ample leave room for future work on the subject.

We now go on to describe the study hypotheses. All variables and symbols used, as well as the expected signs, are presented in Table $3 .^{14}$

The variable that we seek to explain is measured in terms of tons of industrial waste generated at the level of the regions for each unit of gross regional product in real terms

\footnotetext{
${ }^{14}$ Data for the key descriptive statistics and the correlation matrix for the main variables are provided in Tables A1 and A2 in the Appendix.
} 
TABLE 3. Expected Signs for Key Study Variables

\begin{tabular}{|c|c|c|}
\hline Symbol & Description of the Variables & Expected Sign \\
\hline GREENTAX $_{i t}$ & Fiscal disincentive for industrial pollution in each region & - \\
\hline$B U S I N V_{i t}$ & $\begin{array}{l}\text { Business investment in technological innovation associated with greater } \\
\text { environmental awareness }\end{array}$ & - \\
\hline PCINCOME $_{i t}$ & $\begin{array}{l}\text { Income elasticity for the generation of industrial waste, or relative } \\
\text { wealth of regions }\end{array}$ & + \\
\hline$P O P A G E_{i t}$ & Least environmentally sensitive population stratum (age) & + \\
\hline POPSTUDIES $_{i t}$ & Least environmentally sensitive population stratum (education) & + \\
\hline$V A B I N D_{i t}$ & $\begin{array}{l}\text { Regional output specialization (relative size of the manufacturing } \\
\text { sector) }\end{array}$ & + \\
\hline$V A B C O N S T_{i t}$ & Regional output specialization (relative size of the construction sector) & + \\
\hline$V A B E N E R G_{i t}$ & Regional output specialization (relative size of the energy sector) & + \\
\hline
\end{tabular}

$\left(I N D W A S T E_{i t}\right),{ }^{15}$ where $i$ denotes one of Spains 17 regions and $t$ denotes a year between 2000 to 2005.

Our key variable is the green tax on industrial waste. It is intended to reveal whether the mean green charges paid in each region deter pollution, given that industrial activity produces negative environmental outcomes. Since this is a price effect, it seems reasonable to suppose that a tax would reduce the amount of waste generated. We test this argument by using the ratio of green tax revenues by region to the amount of waste generated ( $€ /$ ton) in constant euros $\left(G R E E N T A X_{i t}\right)$. In the period considered in the study, two regions (Andalusia and Madrid) had established and had data available for green taxes of this kind. The expected sign for this variable is negative.

In addition, we wish to consider the possible impact of corporate investment in environmental protection associated with the management of industrial waste. It seems reasonable to expect a negative relationship between environmental investment in industrial waste management by the firms operating in each region and the final levels of industrial pollution. This will provide an approximation of existing stimuli for the adoption of new technologies associated with greater environmental awareness on the part of economic agents or with the response to green taxes. We have constructed this variable by dividing pollutionrelated environmental expenditure by firms in constant euros among the volume of waste in each region $\left(B U S I N V_{i t}\right)$. The expected sign is negative.

We also test whether certain socio-demographic factors (such as per capita income, the age structure of the population, and levels of education) influence levels of industrial pollution. We believe that the relative wealth of each region may influence the quantity of waste generated, since income is a determining factor for demand and pollution is a byproduct of the production of normal goods. Indeed, we expect people to create more waste as their income rises simply because they tend to consume more. We have constructed this variable as the per capita income of each region measured in real terms $\left(P C I N C O M E_{i t}\right)$. We, therefore, expect a positive sign.

\footnotetext{
${ }^{15}$ The construction of this variable is based on the idea of dissociating the generation of waste from economic growth. The data are taken from the Industrial Waste Generation Survey, which is conducted in accordance with the Waste Statistics Regulation 2150/2002 approved by the European Parliament. The main purpose of the survey is to quantify the waste generated in the economic activities classed under sections C, D, and E of the Spanish Classification of Economic Activities (CNAE-93). These activities consist of extractive industries, manufacturing, and gas and electricity generation and distribution. Recycling activities and radioactive waste are excluded from the survey population
} 
As shown by the World Values Survey and the European Values Survey, meanwhile, the relative size of certain population groups, classified in terms of age, may indicate whether the inhabitants of a given region are likely to be less concerned with green issues, in which case higher levels of industrial waste may be expected. The larger the population of older people, the more likely that public opinion will be less aware of environmental problems and thus the more likely that more waste will be generated. We have defined the population age variable $\left(P O P A G E_{i t}\right)$ as the percentage of the population aged over 65 years in each region, and we expect its effect on the dependent variable will be positive.

Likewise, we hypothesize that regions with a large share of population with a relatively low level of education will tend to have less concern for green issues and, therefore, increase the likelihood of higher levels of industrial pollution. We have used the percentage of the population with primary level education to define the educational level of the population (POPSTUDIES (P) $_{\text {) }}$ We expect the influence of this variable on the volume of industrial waste generated to be positive.

Finally, we shall include a variable to capture the possible impact of regional production structures on the generation of industrial waste. This hypothesis is represented through three variables capturing the relative size of each branch of industry (manufacturing, construction and energy) in terms of gross regional product $\left(V A B I N D_{i t}, V A B C O N S T_{i t}\right.$, and $V A B E N E R G_{i t}$ ) and are constructed as the ratio of VAB in each branch of activity and region to regional Gross Domestic Product. We expect a positive sign.

We estimate a logarithmic model for regional waste generation per unit of regional output (INDWASTE) based on panel data and fixed effects with time dummies, as follows:

$$
\begin{gathered}
\text { (1) INDWASTE } \text { It }_{i t}=\mathrm{D}\left(\text { GREENTAX }_{i t} \text { BUSINV }_{i t} \text { PCINCOME }_{i t}, \text { POPAGE }_{i t} \text { POPSTUDIES }_{i t}\right. \\
\text { VABIND }_{i t}, \text { VABCONST } \\
i t
\end{gathered}
$$

We tested for the presence or absence of certain common problems with estimations of this kind, finding evidence for the presence of heteroscedasticity, in view of which we proceeded using White's consistent estimation method. We also looked at the possibility of autocorrelation of perturbation and again found relevant problems. These were solved employing feasible generalized least squares. We also checked the endogeneity of the explanatory variables (GREENTAX and PCINCOME) using the Hausman test: the hypothesis was rejected. ${ }^{16}$ Since spatial autocorrelation can pose problems in estimates including variables with a strong territorial component, we calculated conventional spatial statistics using exploratory Spatial Data Analysis to test for its presence or absence. This was done for a cross section of the mean values of the variables for the entire of study period (Appendix Tables A4 and A5). We concluded that no significant problems of spatial autocorrelation exist. $^{17}$

\footnotetext{
${ }^{16}$ We have analyzed the Lagrange causality test to check for the presence of bi-directionality in the relationship between the endogenous variable and GREENTAX and PCINCOME (Table A3). This test shows that GREENTAX and PCINCOME influence the generation of industrial waste, but not vice versa. Nevertheless, conclusions based on a small sample warrant considerable caution, as the conventional tests may not be valid. Consequently, we apply a quasi-experimental approach in this section, which may be valuable and will at least ensure robust results for the different estimates made.

${ }^{17}$ We compute three measures of global spatial autocorrelation: Moran's I (Moran, 1948), Geary's c (Geary, 1954), and Getis and Ord's G (Getis and Ord, 1992). These measures of global spatial autocorrelation offer an "average" picture of the spatial distribution of the variable concerned and, therefore, they may hide interesting features of the phenomenon analyzed. Several measures of local spatial autocorrelation have been devised in the last decade to overcome this limitation. Local statistics are employed to detect significant spatial clustering around individual locations, sometimes referred to as hotspots. We compute four local spatial autocorrelation statistics: Moran's $I_{i}$, Geary's c $c_{i}$, Getis and Ord's $G_{i}$, and Getis and Ord's $G_{i}{ }^{*}$ (for details and formulas, see Getis and Ord, 1992; Anselin, 1995; Sokal, Oden and Thomson, 1998). This analysis was also
} 
The indication of a significant pattern of spatial clustering given by spatial autocorrelation statistics represents only the first step in the analysis of spatial data. Consequently, we decided to test for possible misspecification of the standard OLS regression model, despite the absence of any evidence that might indicate territorial behavior. When the observations are spatial units (i.e., regions), the standard OLS regression model may be misspecified because of the presence of spatial dependence among observations. ${ }^{18}$ Consequently, we performed the analysis for different sets of data, using the mean values for the variables for the whole of the period analyzed or selecting different years before and after the introduction of the green tax. This required simplifying the model since the temporal dimension was lost along with numerous observations. ${ }^{19}$ We provide the values for the statistics mentioned in the case where we take the mean scores for the variables over the whole of the period analyzed (Appendix Table A6). The results for the other scenarios considered (selection of different years before and after the introduction of the green tax) do not differ significantly.

Let us now analyze the results obtained, which are presented in Table $4 .{ }^{20}$ The sign for the mean green tax charged with respect to the environmental harm caused by the generation of industrial waste is negative, and the levy therefore contributes to rationalizing the environmental impact of industrial activities, although the effect is very limited. Taking the decentralized context of green taxes on industrial waste into account, however, we cannot conclude that the overall outcomes of regional tax design meet the objective of environmental conservation, since one of the two regions levying a charge on waste in the study period presents a non-significant coefficient for the mean green tax at the usual levels of confidence. This region, then, has established average tax rates that do not provide a disincentive for the generation of industrial waste. ${ }^{21}$

Among the possible explanations for this result, we highlight three in particular. First and foremost, tax rates are set arbitrarily without any environmental impact studies, and are too low to incentivize changes in behavior on the part of economic agents. Second, the existence of green taxes at the level of the regions can have environmental purpose, but is intended rather to mitigate financial shortfalls and the limited autonomy of the regional funding system by creating new taxes that enjoy widespread social consensus. Finally, economic agents may react to green taxes on dumped industrial waste by arranging for disposal in other lower-cost regions or, worse, by dumping unlawful. In this light, we believe

carried out for different sub-samples of the data (selecting different years before and after the introduction of the green tax), and again the results pointed to the conclusion that spatial autocorrelation was absent. However, the results that would be obtained if the data were available at a more disaggregated level are uncertain.

${ }^{18}$ In this instance, two kinds of spatial dependence will be considered. The first takes the form of a spatial autoregressive process in the error term. The second takes the form of a mixed regressive spatial autoregressive process. We refer to this model as the spatial lag model (Anselin and Hudak, 1992). We estimate three tests for spatial error dependence (Moran's $\mathrm{I}_{\lambda}$, simple Lagrange multiplier $\mathrm{LM}_{\lambda}$, and robust Lagrange multiplier $\mathrm{LM}_{\lambda}{ }^{*}$ ), and two tests for spatial lag dependence (simple Lagrange multiplier $\mathrm{LM}_{\rho}$ and robust Lagrange multiplier $\left.\mathrm{LM}_{\rho}{ }^{*}\right) . \mathrm{I}_{\lambda}$ and $\mathrm{LM}_{\lambda}$ test for the null hypothesis that $\lambda=0$, while $\mathrm{LM}_{\rho}$ tests that $\rho=0$. When testing for $\lambda=0$, however, $I_{\lambda}$ and $L_{\lambda}$ also respond to nonzero $\rho$; likewise, when testing for $\rho=0, L_{\rho}$ also corresponds to nonzero $\lambda$. The robust tests $\mathrm{LM}_{\lambda}{ }^{*}$ and $\mathrm{LM}_{\rho}{ }^{*}$ have been devised to avoid this problem. For details and formulas pertaining to all of these tests, see Anselin and Hudak (1992) and Anselin et al. (1996).

${ }^{19}$ The two changes made to simplify the model consist of the elimination of demographic variables and the combination of the three economic sectors originally considered in terms of relative significance in a single variable.

20 Readers should treat the results obtained with caution, as the data contain only a very small variation in the dependent variable, which could affect the robustness of the econometric estimates.

${ }^{21}$ It is not our intention to evaluate the optimal level of environmental taxes on waste based on these results, a matter that is beyond the scope of our analysis. If, however, price taxation schemes achieve some reduction in waste production, this moves the outcome in the efficient direction. 


\section{TABLE 4. Logarithmic Estimation of the Industrial Waste using a Panel with Fixed Effects and Time Dummies}

\begin{tabular}{|c|c|c|c|c|}
\hline & \multicolumn{2}{|c|}{ General model } & \multicolumn{2}{|c|}{$\begin{array}{l}\text { Model containing tax } \\
\text { decentralization }\end{array}$} \\
\hline & Coefficient & $t$-statistic & Coefficient & $t$-statistic \\
\hline GREENTAX & $-0.02149 * *$ & -3.03 & & \\
\hline REGandalusia *GREENTAX & & & -0.01429 & -1.20 \\
\hline REGmadrid*GREENTAX & & & $-0.01084 *$ & -1.97 \\
\hline BUSINV & $-0.55382 * *$ & -7.95 & $-0.56485^{* *}$ & -7.64 \\
\hline PCINCOME & $-7.38049 * *$ & -2.84 & $-7.38087 * *$ & -2.61 \\
\hline POPSTUDIES & 0.05826 & 0.54 & 0.05264 & 0.49 \\
\hline POPAGE & $9.95139 * *$ & 3.35 & $9.70283 * *$ & 3.22 \\
\hline$V A B I N D$ & $3.85612 * *$ & 2.70 & $4.28501 * *$ & 2.99 \\
\hline$V A B C O N S T$ & $4.33542 * *$ & 2.93 & $4.08869 * *$ & 2.73 \\
\hline VABENERG & $-0.67426^{*}$ & -2.08 & $-0.67681 *$ & -1.87 \\
\hline$R^{2}$ & \multicolumn{2}{|c|}{0.984} & \multicolumn{2}{|c|}{0.986} \\
\hline Adjusted $R^{2}$ & \multicolumn{2}{|c|}{0.965} & \multicolumn{2}{|c|}{0.966} \\
\hline LM het. test & \multicolumn{2}{|c|}{16.68} & \multicolumn{2}{|c|}{13.78} \\
\hline Durbin-Watson statistic & \multicolumn{2}{|c|}{2.24} & \multicolumn{2}{|c|}{2.26} \\
\hline$F$-statistic & \multicolumn{2}{|c|}{65.60} & \multicolumn{2}{|c|}{62.15} \\
\hline Hausman endogeneity test & \multicolumn{2}{|c|}{2.35} & \multicolumn{2}{|c|}{2.72} \\
\hline
\end{tabular}

* Significantly different from 0 with a confidence level of 95 percent in a two-tailed test.

** Significantly different from 0 with a confidence level of 99 percent in a two-tailed test

$\mathrm{e}$ it is prudent to advise that environmental issues related to the generation of industrial waste be managed by the federal government or that a national fiscal standard be established, the minimum of which would be mandatory for all regions. Still, beyond the minimum, each region could decide the steepness of the green tax rates. ${ }^{22}$

We find evidence that investments made by firms in new technologies to manage the industrial environmental impacts helped to reduce the level of waste generation. That is, the sign of BUSINV is negative and significantly different from zero, as hypothesized.

Based on the variable measuring the relative wealth of the Spanish regions (PCINCOME), we can conclude that income elasticity is negative. This suggests the generation of industrial waste is an inferior good and not a normal good as was hypothesized. This unexpected finding may be explained by arguing from the hypothetical propensity of agents as they become richer to relocate highly polluting products to less-developed regions with lower levels of environmental protection (Panayotou, 2000). It is also possible that this result reflects the fact that the average propensity to consume decreases as wealth increases. ${ }^{23}$

Meanwhile, the demographic variables indicate that levels of waste generation are indeed higher in those regions with a larger share of elderly inhabitants. The coefficient

\footnotetext{
${ }^{22}$ Cutter and DeShazo (2007) discuss the implications of decentralizing environmental policy decisions. In the context of inspection rates, they compare the consequences of different alternatives and, in light of their results, decentralization down to the local level may in fact be worth considering, given a degree of control at higher tiers of government.

${ }^{23}$ In order to test whether the behavior observed with regard to the generation of industrial waste is in line with the Kuznets Environmental Curve, we have included the quadratic term of income in additional estimates, the results of which are given in Table 7.A in the appendix. However, we found no evidence of alignment with the Kuznets Environmental Curve, since this would require a positive coefficient for PCINCOME and a negative coefficient for PCINCOME ${ }^{2}$, as Capó (2008) argues. Our results are in line with other studies, which do not find any simple, predictable relationship between any measure of environmental quality and growth (Roca et al., 2001; Harbaugh et al., 2002; Plassmann and Khanna, 2006).
} 
obtained was not significant for the variable denoting lower-than-average levels of education in the region, however.

Finally, the variable designed to capture any economic specialization effects points to a statistically significant positive value that derives from the relative size of the industrial and construction sector. This indicates that environmental damage is greater in those regions where industry and construction account for a larger share of the economy. Meanwhile, a negative coefficient for the energy sector share of gross regional product suggests that regions specializing in power generation actually produce less waste. We believe these results are associated with the relative importance of different sectors in the generation of waste

To test the robustness of our results we carried out two additional econometric estimates based using Wooldridge's (2002) reasoning with the aim of forming an idea of the effectiveness of green tax policies in reducing industrial waste. First, given the availability of data both before and after the change in green tax policy and using the difference-indifferences estimator, we controlled for systematic differences between the group of regions that applied such charges and the group that does not. Let us call the control group A and the treatment group B to construct a qualitative variable $(d B)$ that takes a value of one for regions applying the tax and zero for those that do not. We then created a dummy variable $d 2$ that assigns a value of one to those years in which a green tax is applied and a variable of zero to those in which it is not. Taking both variables and controlling for possible time effects using dummies, we constructed the following logarithmic model, which was estimated using the generalized least squares method (to solve any autocorrelation problems), correcting for the problem of heteroscedasticity:

(2) INDWASTE $_{i t}=\beta_{0}+\delta_{0} d 2+\beta_{1} d B+\delta_{1} \mathrm{~d} 2 d B+\beta_{2}$ BUSINV $_{i t}+\beta_{3}$ PCINCOME $_{i t}+\beta_{4}$ POPAGE ${ }_{i t}+\beta_{5}$ POPSTUDIES $_{i t}+\beta_{6}$ VABIND $_{i t}+\beta_{7}$ VABCONST $_{i t}+\beta_{8}$ VABENERG $_{i t}+$ $\delta_{2} t 01+\delta_{3} t 02+\delta_{4} t 03+\delta_{5} t 04+\delta_{6} t 05$

As shown in Table 5, the results obtained from the estimation of Equation (2) for the difference-in-differences estimator $\left(\delta_{1}\right)$ reveal that growth in the amount of waste generated in those regions that have a green tax on industrial waste was 27 percent lower than the growth in regions where no environmental charges are applied. However, this result is only statistically significant at the 10 percent level with a two-tailed test. ${ }^{24}$

The second alternative consists in taking the original model in differences to eliminate the unobservable effects (or fixed effects) in each region. This removes any possible systematic association that may exist between such unobservable features and the application of green taxes to industrial waste. In this case, it is necessary to eliminate structural explanatory variables displaying scant change over time because the model uses a differences approach. Meanwhile, we include a fictitious variable that takes a value of one for those regions that have a green tax in place in the year considered and a value of zero otherwise (ECOTAX). Fictitious variables are included for each year analyzed to control for possible time effects $(\Delta \mathrm{T} 2001-\Delta \mathrm{T} 2005)$. Hence, the model robustly estimated using logarithms and differences is:

(3) $\Delta \log \left(\right.$ INDWASTE $\left._{i t}\right)=\beta_{0}+\beta_{1} \Delta$ ECOTAX $_{i t}+\beta_{2} \Delta \log \left(\right.$ BUSINV $\left._{i t}\right)+\beta_{3} \Delta \log \left(\right.$ PCINCOME $\left._{i t}\right)+$ $\alpha_{1} \Delta T 2001+\alpha_{2} \Delta T 2002+\alpha_{3} \Delta T 2003+\alpha_{4} \Delta T 2004+\alpha_{5} \Delta T 2005$

\footnotetext{
${ }^{24}$ This result shows regions that have established a green tax have succeeded only in slowing the rate of growth in waste production as compared to those that have not. However, they have not been able halt this growth, as shown by the statistically significant, positive $\beta_{1}$ coefficient.
} 
TABLE 5. Calculation of the Difference-in-Differences Estimator between Green Tax and Nongreen Tax Regions (with Time Dummy Variables)

\begin{tabular}{lcr}
\hline \hline & Coefficient & t-Statistic \\
\hline$\beta_{0}$ & $30.51435^{* *}$ & 5.65 \\
$\beta_{1} d B$ & $1.248791^{*}$ & 2.36 \\
$\delta_{0} d 2$ & 0.047657 & 0.40 \\
$\delta_{1} d 2 d B$ & -0.271182 & -1.67 \\
$\beta_{2}$ BUSINV & $-0.415759 * *$ & -5.67 \\
$\beta_{3}$ PCINCOME & $-2.973499 *$ & -2.37 \\
$\beta_{5}$ POPSTUDIES & 0.102168 & 0.74 \\
$\beta_{4}$ POPAGE & $2.693039 *$ & 2.10 \\
$\beta_{6}$ VABIND & $1.865160 * *$ & 2.82 \\
$\beta_{7}$ VABCONST & -1.273737 & -1.15 \\
$\beta_{8}$ VABENERG & 0.359052 & 1.26 \\
$R^{2}$ & 0.91 & \\
Adjusted $R^{2}$ & 0.899 & \\
\hline \hline * Significantly different from 0 with a confidence level of 95 percent with a two-tailed test. & \\
$* *$ Significantly different from 0 with a confidence level of 99 percent with a two-tailed test &
\end{tabular}

TABLE 6. Calculation of the Model in Differenced Logs

\begin{tabular}{lrr}
\hline \hline & Coefficient & $t$-statistic \\
\hline$\beta_{0}$ & $15.42144^{* *}$ & 4.02 \\
$\beta_{1} \Delta E C O T A X$ & $-0.145736^{*}$ & -2.26 \\
$\beta_{2} \Delta \log ($ BUSINV $)$ & $-0.370668^{* *}$ & -3.99 \\
$\beta_{3} \Delta \log ($ PCINCOME $)$ & -3.502612 & -0.76 \\
$\alpha_{1} \Delta T 01$ & $-15.55556^{* *}$ & -4.06 \\
$\alpha_{2} \Delta T 02$ & $-30.72374 * *$ & -4.05 \\
$\alpha_{3} \Delta T 03$ & $-46.00461 * *$ & -4.05 \\
$\alpha_{4} \Delta T 04$ & $-61.10862^{* *}$ & -4.03 \\
$\alpha_{5} \Delta T 05$ & $-76.39539 * *$ & -4.04 \\
$R^{2}$ & 0.513 & \\
Adjusted $R^{2}$ & 0.471 & \\
\hline \hline
\end{tabular}

* Significantly different from 0 with a confidence level of 95 percent with a two-tailed test.

** Significantly different from 0 with a confidence level of 99 percent with a two-tailed test

As may be observed in Table 6, the results obtained from the estimation of Equation (3) for the logarithms and differences model reveal that those regions that have levied a green tax on industrial waste have achieved a 14 percent reduction in the growth in waste generation compared to regions that have no such charge. This result is statistically significant at the 5 percent level. This is the most robust of the models estimated (from the point of view of its formulation), and we may conclude in view of the results that the regions with the tax in place had lower waste than they would have had without the tax in place in those years.

Anyway, since conclusions based on such a small sample warrant considerable caution, we consider that a quasi-experimental approach might be valuable, or at least provide a more robust approach. Thus, the comparison of a region applying green charges with neighboring regions that have not established any green charge could be added as a robustness check. We have calculated mean waste generation for the regions that have introduced green taxes and for their neighboring regions. Table 7 shows that the regions that 
TABLE 7. Direct (Non-regression) Means Approach (Tons of Industrial Waste)

\begin{tabular}{lcl}
\hline \hline Treatment group & \multicolumn{1}{c}{$\begin{array}{c}\text { Control group } \\
\text { (neighboring regions) }\end{array}$} \\
\hline Before & $\begin{array}{c}\text { CB: } 26,118,180 \\
\text { Andalusia (1999-2003) }\end{array}$ & $\begin{array}{c}\text { Extremadura (1999-2003) } \\
\text { Castile-La Mancha (1999-2003) } \\
\text { Murcia (1999-2003) }\end{array}$ \\
& Madrid (1999-637-2002) & Castile-Leon (1999-2002) \\
After & Castile-La Mancha (1999-2002) & CA: 27,484,191 \\
& Andalusia (2004-2005) $3,765,887$ & Extremadura (2004-2005) \\
& Castile-La Mancha (2004-2005) \\
& Murcia (2004-2005) \\
Madrid (2003-2005) & Castile-Leon (2003-2005) \\
& Castile-La Mancha (2003-2005) \\
\hline
\end{tabular}

have established green charges generate less waste than those that have not (treatment effect $=(\mathrm{TA}-\mathrm{TB})-(\mathrm{CA}-\mathrm{CB})=-2,529,761){ }^{25}$

To support our analysis, we present Figure 1. It is a graphical representation of the waste trends for the treatment and control regions and of the overall level of waste produced together with the trend for total waste output, calculated using a straightforward growth style regression model (with a lagged dependent value and time trend). ${ }^{26}$ This graphic analysis throws light on the results obtained. Specifically, the estimations of the difference-indifference models and the quasi-experimental approach show that the treatment regions had higher pollution prior to introducing the green taxes relative to the non-green tax regions. After the introduction of the green taxes, the gap between the two groups was reduced. This suggests that the green taxes were effective in limiting waste output in the regions implementing the tax.

As may be observed in Figure 1, the introduction of green taxes in the Andalusia and Madrid regions in 2003 appears to have halted the upward trend in the production of industrial waste in these regions and in the trend for total waste. Nevertheless, the overall level of waste production in Spain as a whole did not change significantly. This result suggests that some of the waste may have been redirected to non-tax regions. In fact, industrial waste increased in Castile-La Mancha (bordering both Madrid and Andalusia) and Castile-León (bordering Madrid to the north) after 2003, possibly reflecting a partial relocation of waste disposal. So the difference in pollution production between green tax

\footnotetext{
${ }^{25}$ In any event, readers should be aware that the laws establishing environmental taxes on industrial waste were passed in 2003 , and it is therefore likely that the data capture only the short-run impact of these measures.

${ }^{26}$ In the interest of visual clarity, the figure does not include the waste trends for non-neighboring regions. We would also point out that the somewhat erratic evolution of industrial waste production in Andalusia and overall from 2000 to 2001 is due to the sharp contraction in Minerals extraction in this period.
} 
FIGURE 1. Evolution of Industrial Waste Production in Spanish Regions (Metric Tons of Industrial Waste)*

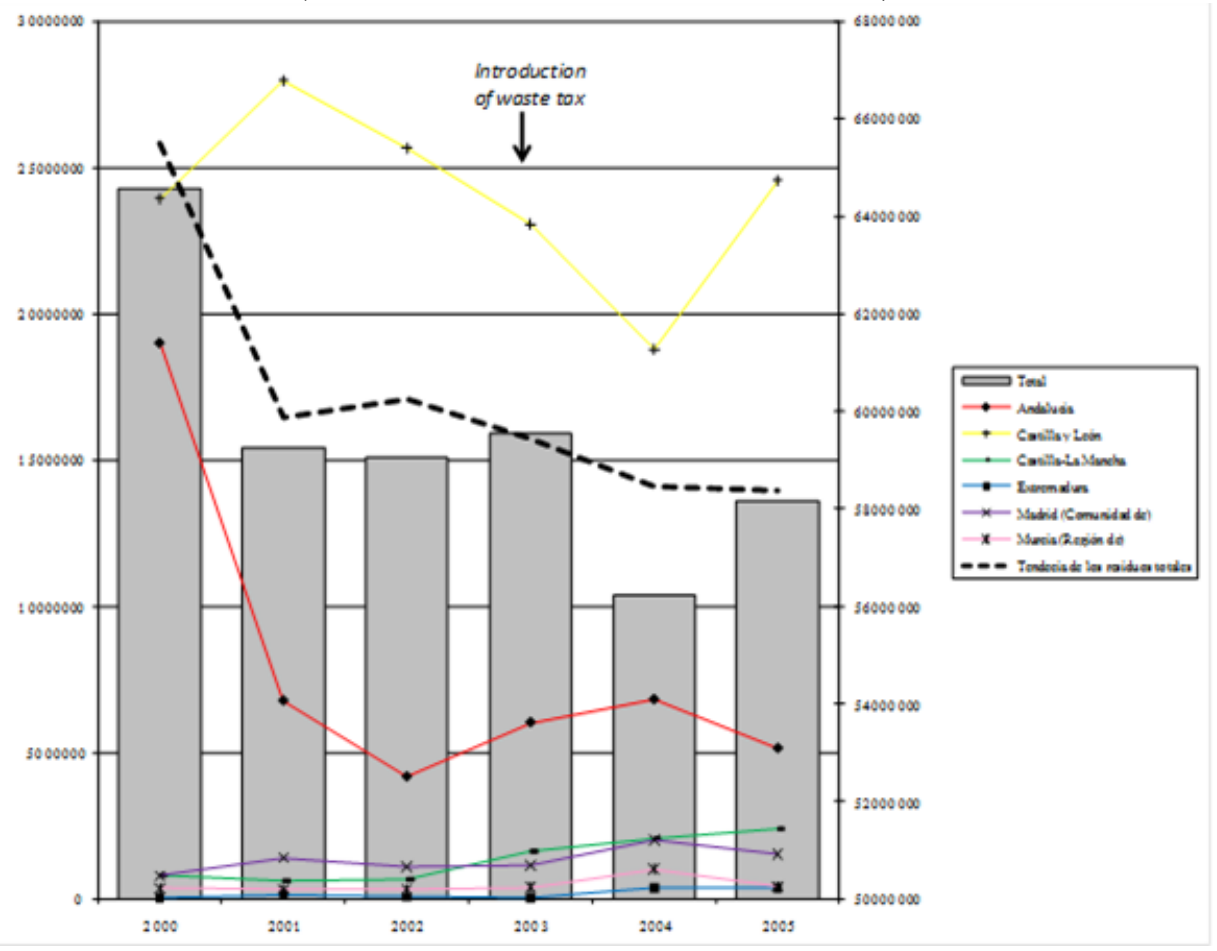

Note: * Total waste and trend (secondary scale).

\section{CONCLUSIONS}

Increasing concern about environmental issues, including the generation of waste, argues in favor of government intervention to improve the effectiveness of environmental management. Various mechanisms exist for the protection of the environment, including regulation, property rights, and the establishment of green taxes. However taxation has considerable advantages over other instruments, because of this, the use of fiscal tools in the environmental policies implemented by developed countries has persistently grown of late.

Having justified the use of green taxes to reduce pollution levels, it is necessary in a federal state to identify the level of government at which such charges can be most effectively levied. Existing theoretical and empirical arguments support the use of environmental Pigouvian taxes at more-local levels of government. This could involve granting local or regional authorities the autonomy to set tax rates and perhaps additionally establishing a minimum national standard for green taxes in order to ensure a base level of environmental quality nationwide. Alternatively, geographical variations in tax rates could be allowed, while reserving decisions and management to the national government to prevent strategic behaviors.

The Spanish experience is particularly interesting in this regard, because each of three tiers of government (national, regional, and local) have the fiscal power to impose green charges on waste, although they presently are only exercised at the subnational level. In this context, the aim of the present study is to determine whether the overall outcomes of greentax decisions taken by regional governments in Spain are encouraging any reduction in the volume of industrial waste generation. Results seem to suggest that they do. Although the empirical specification does not address this explicitly, it also appears that green taxes in Spain are not set at optimal levels. Still, the findings do suggest that the green taxes, regardless of their true purpose, tend to increase environmental efficiency. That is, they 
appear to improve environmental conditions. As most cases, it is changes at the margin that determine the value of policies.

Nevertheless, the model presented in this paper reveals that the tax design implemented at the level of regional government is probably unsuitable in at least one case. It appears that dumping charges tend to be too low because they fail to account for environmental impacts. This may be because such taxes are likely designed only to cover disposal operating costs and to raise some additional revenues to mitigate the limited fiscal powers of the regional government. Meanwhile, it is also likely that businesses react to tax competition from nearby regions and transport their waste to regions where lower or no dumping charge applies or, worse, by dumping illegally.

The results obtained from this study indicate that taxing the waste production at the regional level does not yet produce desirable environmental outcomes. It is therefore reasonable to suppose that, as proposed in the literature, further coordination between regions is needed or that some form of centralized solution is required. The latter would guarantee a standard level of environmental quality nationwide and could still yield some latitude for regional green tax differentials.

\section{REFERENCES}

André, Francisco J. and Emilio Cerdá. (2006) "Gestión de Residuos Sólidos Urbanos. Análisis Económico y Políticas Públicas," Cuadernos Económicos del ICE, 71, 71-91.

Anselin, Luc. (1995) "Local Indicators of Spatial Association-LISA," Geographical Analysis, 27, 93-115.

Anselin, Luc and Sheri Hudak. (1992) "Spatial Econometrics in Practice: A Review of Software Options," Regional Science and Urban Economics, 22, 509-536.

Anselin, Luc, Anil K. Bera, Raymond Florax, and Mann J. Yoon. (1996) "Simple Diagnostic Tests for Spatial Dependence," Regional Science and Urban Economics, 26, 77-104.

Baumol, William J. and Wallace E. Oates. (1988) The Theory of Environmental Policy. Cambridge University Press: Cambridge, U.K.

Capó, Javier (2008) "Crecimiento Económico y Contaminación Atmosférica: Nueva Evidencia a Favor de la Curva de Kuznets Ambiental," III Congreso de la Asociación Hispano-Portuguesa de Economía de los Recursos Naturales y Ambientales, Palma de Mallorca, June 4-6.

Cumberland, John. (1981) "Efficiency and Equity in Interregional Environmental Management," Review of Regional Studies, 10(1), 1-19.

Cutter, W. Bowman and J.R. DeShazo. (2007) "The Environmental Consequences of Decentralizing the Decision to Decentralize," Journal of Environmental Economics and Management, 53, 32-53.

Dalmazzone, Silvana. (2006) "Decentralization and the Environment," in Ehtisham Ahmad and Giorgio Brosio (eds.), Handbook of Fiscal Federalism. Edward Elgar: Cheltenham, U.K., pp. 459-477.

Department of the Environment, Transport and the Regions. (1998) Economic Instruments for Water Pollution. London: DETR. Digital document

Dinan, Terry M., Maureen L. Cropper, and Paul R. Portney. (1999) "Environmental Federalism: Welfare Losses from Uniform National Drinking Water Standards," in Arvind Panagariya, Paul R. Portney, and Robert M. Schwab (eds.), Environmental and

(c) Southern Regional Science Association 2011. 
Public Economics: Essays in Honor of Wallace E. Oates. Edward Elgar: Cheltenham, U.K., pp. 13-31.

Dinan, Terry M. (1993) "Economic Efficiency Effects of Alternative Policies for Reducing Waste Disposal," Journal of Environmental Economics and Management, 25, 242-256.

Field, Barry. (1995) Economía Ambiental (Environmental Economics). McGraw-Hill: Madrid.

Fredriksson, Per G. (2000) "The Siting of Hazardous Waste Facilities in Federal System," Environmental and Resource Economics, 15, 75-87.

Fullerton, Don and Thomas C. Kinnaman. (1995) "Garbage, Recycling, and Illicit Burning or Dumping," Journal of Environmental Economics and Management, 29, 78-91.

Gago, Alberto and Xavier Labandería. (1997) "La Imposición Ambiental: Fundamentos, Tipología Comparada y Experiencias en la OCDE y España," Hacienda Pública, 141$142,193-219$.

Gago, Alberto, Xavier Lavandería, Fidel Picos, and Miguel Rodríguez. (2005) "La Imposición Ambiental Autonómica," in Núria Bosch and José M. Durán (eds.), La Financiación de las Comunidades Autónomas: Políticas Tributarias y Solidaridad Interterritori. Edicions i Publicacions de la Universitat de Barcelona: Barcelona, pp. 86-106.

García-Valiña, Maria A. (2005) "Decentralization and Environment: An Application to Water Policies," Working Paper \#2005.31. Fondazione Eni Enrico Mattei: Milan. Available in February 2011 at http://www.feem.it/userfiles/attach/Publication/NDL2005/NDL2005-031.pdf.

Geary, Roy C. (1954) "The Contiguity Ratio and Statistical Mapping," Incorporated Statistician, 5, 115-146.

Getis, Arthur and J. Keith Ord. (1992) "The Analysis of Spatial Association by Use of Distance Statistics," Geographical Analysis, 24, 189-206.

Glazer, Amihai. (1999) "Local Regulation May Be Excessively Stringent," Regional Science and Urban Economics, 29, 553-558.

Harbaugh, William T., Arik Levinson, and David M. Wilson. (2002) "Reexamining the Empirical Evidence for an Environmental Kuznets Curve," Review of Economics and Statistics, 84, 541-551.

Jaffe, Adam B., Steven R. Peterson, Paul R. Portney, and Robert N. Stavins. (1995) "Environmental Regulation and the Competitiveness of U.S. Manufacturing: What Does the Evidence Tell Us?," Journal of Economic Literature, 33, 132-163.

Kneese, Allen V. (1971) "Environmental Pollution: Economics and Policy," American Economic Review, 61, 153-166.

Kunce Mitch and Jason F. Shogren. (2005) "On Interjurisdictional Competition and Environmental Federalism," Journal of Environmental Economics and Management, $50,212-224$.

Levinson, Arik. (2003) "Environmental Regulatory Competition: A Status Report and Some New Evidence," National Tax Journal, 56, 91-106.

López, Tomás J., Fernando Lara de Vicente, Fernando Fuentes, and Ricardo Veroz. (2006) "La Reforma Fiscal Ecológica en la Unión Europea: Antecedentes, Experiencias y Propuestas," Revista de Economía Institucional, 8, 321-332. 
Markusen, James R., Edward R. Morey, and Nancy Olewiler. (1993) "Environmental Policy When Market Structure and Plant Locations Are Endogenous," Journal of Environmental Economics and Management, 24, 69-86.

. (1995) "Competition in Regional Environmental Policies When Plant Locations Are Endogenous," Journal of Public Economics, 56, 55-77.

Millimet, Daniel L. (2003) “Assessing the Empirical Impact of Environmental Federalism," Journal of Regional Science, 43, 711-733.

Moran, Patrick A.P. (1948) "The Interpretation of Statistical Maps," Journal of the Royal Statistical Society, Series B, 10, 243-251.

Oates, Wallace E. (1972) Fiscal Federalism. Harcourt Brace Jovanovich; New York. . (2002) "A Reconsideration of Environmental Federalism," in John A. List and Aart de Zeeuw (eds.), Recent Advances in Environmental Economics. Edward Elgar Publisher: Cheltenham, U.K., pp. 1-32.

Oates, Wallace E. and Robert M. Schwab. (1988) "Economic Competition among Jurisdictions: Efficiency Enhancing or Distortion Inducing," Journal of Public Economics, 35, 333-354.

OECD. (1989) Economic Instruments for Environmental Protection. OECD: París.

OECD. (1994) Managing the Environment: The Role of Economic Instruments. OECD: París.

Olson, Mancur, Jr.. (1969) “The Principle of 'Fiscal Equivalence': The Division of Responsibilities among Different Levels of Government," American Economic Review, 59, 479-487.

Panayotou, Theodore. (2003) "Economic Growth and the Environment," Chapter 2 of the Economic Survey of Europe, issue 2, 45-72. Last accessed in February 2011 at http://www.unece.org/ead/pub/032/032_c2.pdf.

Peltzman, Sam and T. Nicolaus Tideman. (1972) "Local Versus National Pollution Control: Note," American Economic Review, 62, 959-963.

Plassmann, Florenz and Neha Khanna. (2006) "Household Income and Pollution: Implications for the Debate about the Environmental Kuznets Curve Hypothesis," Journal of Environment and Development, 15, 22-41.

Porter, Richard C. (2002) The Economics of Waste. Resources for the Future: Washington, DC.

Puig, Ignasi. (2001) "Definición de Tasas Municipales de Gestión de Residuos para Incidir en la Reducción y el Reciclaje," in Dolores Romano and Pablo Barrenechea (eds.), Instrumentos Económicos para la Prevención y el Reciclaje de los Residuos Urbanos, Serie General 9. Bakeaz/Fundación Ecología y Desarrollo: Bilbao, Spain, pp. 85-105.

Roca, Jordi, Emilio Padilla, Mariona Farré, and Vittorio Galletto. (2001) "Economic Growth and Atmospheric Pollution in Spain: Discussion the Environmental Kuznets Hypothesis," Ecological Economics, 39, 85-99.

Roelfsema, Hein. (2007) "Strategic Delegation of Environmental Policy Making," Journal of Environmental Economics and Management, 53, 270-275.

Shapiro, Perry and Jeffrey D. Petchey. (1997) "The Welfare Economics of Environmental Regulatory: Two Parables on State vs Federal Control," in John B. Braden and Stef 
Proost (eds.), The Economic Theory of Environmental Policy in a Federal System. Edward Elgar: Cheltenham, UK, pp. 122-146.

Smith, Stephen. (1992) “Taxation and the Environment: A Survey," Fiscal Studies, 13, 2157.

. (1995) "The Role of the European Union in Environmental Taxation," in Lans Bovenberg and Sijbren Cnossen (eds.), Public Economics and the Environment in an Imperfect World. Kluwer Academic Press: Boston, pp. 221-237.

Sokal, Robert R., Neal L. Oden, and Barbara A. Thomson. (1998) "Local Spatial Autocorrelation in a Biological Model," Geographical Analysis, 30, 331-354.

Stein, Jerome L. (1971) “The 1971 Report of the President's Council of Economic Advisers: Micro-Economic Aspects of Public Policy,” American Economic Review, 61, 531-537.

Summer, Lawrence H. (1991) “The Case for Corrective Taxation," National Tax Journal, 44, 289-292.

Taylor, Donald C. (2000) "Policy Incentives to Minimize Generation of Municipal Solid Waste," Waste Management \& Research, 18, 406-419.

Wildasin, David E. (1989) "Interjurisdictional Capital Mobility: Fiscal Externality and Corrective Subsidy,” Journal of Urban Economics, 25, 192-212.

Wilson, John D. (1986) “A Theory of Interregional Tax Competition," Journal of Urban Economics, 19, 296-315.

Wooldridge, Jeffrey M. (2002) Econometric Analysis of Cross Section and Panel Data. MIT Press: Cambridge, MA.

Zodrow, George R. and Peter Mieszkowski. (1986) "Pigou, Tiebout, Property Taxation, and the Underprovision of Local Public Goods," Journal of Urban Economics, 19, 356370. 


\section{Appendix}

TABLE A1. Descriptive Statistics for Key Variables

\begin{tabular}{|c|c|c|c|c|c|c|c|c|}
\hline & Mean & StdDev & Minimum & Maximum & Sum & Variance & Skewness & Kurtosis \\
\hline INDW ASTE & 0.10158 & 0.17786 & 0.00026197 & 0.88291 & 12.08852 & 0.031633 & 2.97406 & 8.22074 \\
\hline GREENTAX & 0.00012463 & 0.00078297 & 0.0 & 0.0058334 & 0.014831 & $6.13048 \mathrm{E}-07$ & 6.66029 & 44.52727 \\
\hline BUSINBV & 5.87144 & 14.46184 & 0.0 & 145.74959 & 698.70150 & 209.14488 & 8.04297 & 75.52137 \\
\hline PCINCOME & 15.13131 & 3.42080 & 8.11398 & 23.15528 & 1800.62590 & 11.70188 & 0.25783 & -0.59849 \\
\hline POPSTUDIES & 12.96609 & 6.81375 & 0.72742 & 26.80285 & 1542.96453 & 46.42713 & 0.33730 & -0.97985 \\
\hline POPAGE & 17.50697 & 2.97585 & 11.42699 & 22.36858 & 2083.32906 & 8.85570 & -0.23901 & -0.94911 \\
\hline$V A B I N D$ & 17.12013 & 7.15788 & 4.59566 & 31.21024 & 2037.29523 & 51.23529 & -0.097025 & -0.86168 \\
\hline$V A B C O N S T$ & 10.02466 & 1.82120 & 6.72536 & 15.56797 & 1192.93490 & 3.31678 & 0.44826 & -0.08605 \\
\hline$V A B E N E R G$ & 3.06738 & 1.26323 & 1.18019 & 6.56391 & 365.01837 & 1.59576 & 0.75888 & -0.12212 \\
\hline
\end{tabular}

TABLE A2. Correlation Matrix of Key Variables

\begin{tabular}{|c|c|c|c|c|c|c|c|c|}
\hline variable & GREENTAX & BUSINBV & PCINCOME & POPSTUDIES & POPSTUDIES & $V A B I N D$ & VABCONST & VABENERG \\
\hline GREENTAX & 1.00000 & & & & & & & \\
\hline BUSINBV & 0.077225 & 1.00000 & & & & & & \\
\hline PCINCOME & 0.20242 & 0.29950 & 1.0000 & & & & & \\
\hline POPSTUDIES & -0.012960 & -0.13110 & -0.63729 & 1.0000 & & & & \\
\hline POPAGE & -0.32171 & -0.010763 & -0.13210 & -0.30935 & 1.00000 & & & \\
\hline$V A B I N D$ & -0.26441 & -0.070441 & 0.27036 & -0.49667 & 0.59958 & 1.00000 & & \\
\hline VABCONST & 0.10378 & 0.40530 & -0.25234 & 0.15764 & 0.13592 & -0.35461 & 1.00000 & \\
\hline$V A B E N E R G$ & -0.18264 & -0.076334 & -0.48795 & 0.37953 & 0.45855 & 0.0019153 & 0.36497 & 1.0000 \\
\hline
\end{tabular}

TABLE A3. Granger Causality Test (Exogeneity Wald Test $-\chi^{2}$ )

\begin{tabular}{l|ccc}
\hline \hline variable & INDWASTE & GREENTAX & PCINCOME \\
\hline INDWASTE & & 3.715 & 0.237 \\
GREENTAX & $14.467 *$ & & 0.221 \\
PCINCOME & 1.562 & 6.010 & \\
ALL & $15.989 *$ & 9.171 & 0.452 \\
\hline \hline
\end{tabular}

Note: * Significant with a confidence level of 95 percent. 
TABLE A4. Measures of Global Spatial Autocorrelation

\begin{tabular}{|c|c|c|c|c|c|c|c|c|c|c|c|c|c|c|c|}
\hline \multirow[b]{2}{*}{ Variables } & \multicolumn{5}{|c|}{ Moran's I } & \multicolumn{5}{|c|}{ Geary's c } & \multicolumn{5}{|c|}{ Getis \& Ord's G } \\
\hline & I & $\mathrm{E}(\mathrm{I})$ & $\operatorname{sd}(\mathrm{I})$ & $z$ & $p$-value* & $\mathrm{c}$ & $\mathrm{E}(\mathrm{c})$ & $\operatorname{sd}(\mathrm{c})$ & $z$ & $p$-value* & G & $\mathrm{E}(\mathrm{G})$ & $\operatorname{sd}(G)$ & $z$ & $p$-value* \\
\hline INDWASTE & -0.214 & -0.063 & 0.159 & -0.954 & 0.340 & 1,020 & 1,000 & 0.195 & 0.100 & 0.920 & 0.338 & 0.243 & 0.074 & 1,277 & 0.202 \\
\hline GREENTAX & -0.079 & -0.063 & 0.134 & -0.124 & 0.901 & 0.865 & 1,000 & 0.254 & -0.532 & 0.595 & 0.252 & 0.243 & 0.014 & 1,377 & 0.162 \\
\hline BUSINV & -0.083 & -0.063 & 0.162 & -0.127 & 0.899 & 1,014 & 1,000 & 0.185 & 0.077 & 0.938 & 0.236 & 0.243 & 0.005 & $-1,284$ & 0.199 \\
\hline PCINCOME & -0.092 & -0.063 & 0.164 & -0.179 & 0.858 & 1,009 & 1,000 & 0.180 & 0.049 & 0.961 & 0.238 & 0.243 & 0.005 & -0.954 & 0.340 \\
\hline VABIND & 0.048 & -0.063 & 0.158 & 0.700 & 0.484 & 0.745 & 1,000 & 0.196 & $-1,301$ & 0.193 & 0.251 & 0.243 & 0.005 & 1,732 & 0.083 \\
\hline
\end{tabular}

*two-tailed test

TABLE A5. Measures of Local Spatial Autocorrelation to INDWASTE

\begin{tabular}{|c|c|c|c|c|c|c|c|c|c|c|c|c|c|c|c|}
\hline \multirow[b]{2}{*}{ Region } & \multicolumn{5}{|c|}{ Moran's $I_{i}$} & \multicolumn{5}{|c|}{ Getis \& Ord's $G_{1 i}$} & \multicolumn{5}{|c|}{ Getis \& Ord's $G_{2 i}$} \\
\hline & Ii & $\mathrm{E}\left(\mathrm{I}_{\mathrm{i}}\right)$ & $\operatorname{sd}\left(I_{i}\right)$ & $z$ & $p$-value* & $\mathrm{G}_{1 \mathrm{i}}$ & $\mathrm{E}\left(\mathrm{G}_{1 \mathrm{i}}\right)$ & $\operatorname{sd}\left(\mathrm{G}_{1 \mathrm{i}}\right)$ & $z$ & $p$-value* & $\mathrm{G}_{2 \mathrm{i}}$ & $\mathrm{E}\left(\mathrm{G}_{2 \mathrm{i}}\right)$ & $\operatorname{sd}\left(G_{2 i}\right)$ & $z$ & $p$-value* \\
\hline 1 & -0.27 & -0.06 & 0.43 & -0.47 & 0.64 & 0.14 & 0.25 & 0.11 & -0.96 & 0.34 & 0.22 & 0.29 & 0.11 & -0.69 & 0.49 \\
\hline 2 & 0.29 & -0.06 & 0.32 & 1.09 & 0.28 & 0.54 & 0.38 & 0.13 & 1.31 & 0.19 & 0.59 & 0.41 & 0.12 & 1.48 & 0.14 \\
\hline 3 & 0.53 & -0.06 & 0.51 & 1.16 & 0.25 & 0.28 & 0.19 & 0.10 & 0.87 & 0.39 & 0.38 & 0.24 & 0.10 & 1.42 & 0.16 \\
\hline 4 & -2.15 & -0.06 & 0.64 & -3.23 & 0.00 & 0.23 & 0.13 & 0.07 & 1.59 & 0.11 & 0.19 & 0.18 & 0.09 & 0.15 & 0.88 \\
\hline 5 & -1.01 & -0.06 & 0.94 & -1.01 & 0.31 & 0.09 & 0.06 & 0.05 & 0.48 & 0.63 & 0.05 & 0.12 & 0.08 & -0.92 & 0.36 \\
\hline 6 & 0.15 & -0.06 & 0.51 & 0.41 & 0.68 & 0.29 & 0.19 & 0.10 & 0.99 & 0.32 & 0.34 & 0.24 & 0.10 & 1.03 & 0.30 \\
\hline 7 & -0.68 & -0.06 & 0.51 & -1.21 & 0.23 & 0.14 & 0.19 & 0.10 & -0.45 & 0.65 & 0.29 & 0.24 & 0.10 & 0.54 & 0.59 \\
\hline 8 & 0.10 & -0.06 & 0.51 & 0.31 & 0.76 & 0.27 & 0.19 & 0.10 & 0.81 & 0.42 & 0.32 & 0.24 & 0.10 & 0.84 & 0.40 \\
\hline 9 & 0.07 & -0.06 & 0.64 & 0.20 & 0.84 & 0.26 & 0.13 & 0.08 & 1.58 & 0.11 & 0.30 & 0.18 & 0.09 & 1.41 & 0.16 \\
\hline 10 & 0.00 & -0.06 & 0.29 & 0.23 & 0.82 & 0.51 & 0.44 & 0.13 & 0.54 & 0.59 & 0.54 & 0.47 & 0.12 & 0.54 & 0.59 \\
\hline 11 & -0.21 & -0.06 & 0.43 & -0.35 & 0.73 & 0.30 & 0.25 & 0.10 & 0.47 & 0.64 & 0.31 & 0.29 & 0.11 & 0.13 & 0.90 \\
\hline 12 & 0.05 & -0.06 & 0.21 & 0.52 & 0.60 & 0.69 & 0.63 & 0.13 & 0.53 & 0.60 & 0.72 & 0.65 & 0.11 & 0.66 & 0.51 \\
\hline 13 & -0.36 & -0.06 & 0.64 & -0.47 & 0.64 & 0.16 & 0.13 & 0.08 & 0.45 & 0.65 & 0.16 & 0.18 & 0.09 & -0.15 & 0.88 \\
\hline 14 & -0.08 & -0.06 & 0.51 & -0.04 & 0.97 & 0.23 & 0.19 & 0.10 & 0.43 & 0.66 & 0.26 & 0.24 & 0.10 & 0.25 & 0.80 \\
\hline 15 & 0.02 & -0.06 & 0.37 & 0.22 & 0.83 & 0.34 & 0.31 & 0.12 & 0.26 & 0.79 & 0.39 & 0.35 & 0.11 & 0.33 & 0.74 \\
\hline 16 & 0.00 & -0.06 & 0.43 & 0.15 & 0.88 & 0.26 & 0.25 & 0.11 & 0.04 & 0.97 & 0.31 & 0.29 & 0.11 & 0.13 & 0.90 \\
\hline 17 & -0.07 & -0.06 & 0.43 & -0.02 & 0.99 & 0.27 & 0.25 & 0.10 & 0.15 & 0.88 & 0.28 & 0.29 & 0.11 & -0.10 & 0.92 \\
\hline
\end{tabular}

*two-tailed test

(c) Southern Regional Science Association 2011. 
TABLE A6. Diagnostic Tests for Spatial Dependence in OLS Regression

\begin{tabular}{lcc}
\hline \hline Test & Statistic & $p$-value \\
Spatial error: & & \\
$\quad$ Moran's I & -0.556 & 1.422 \\
Lagrange multiplier & 0.638 & 0.425 \\
$\quad$ Robust Lagrange multiplier & 0.045 & 0.832 \\
Spatial lag: & & \\
$\quad$ Lagrange multiplier & 1.135 & 0.287 \\
$\quad$ Robust Lagrange multiplier & 0.542 & 0.462 \\
\hline \hline
\end{tabular}

TABLE A7. Logarithmic Estimation of the Industrial Waste Model with Fixed Effects and Time Dummies

\begin{tabular}{|c|c|c|c|c|}
\hline \multirow[b]{2}{*}{ variables } & \multicolumn{2}{|c|}{ General model } & \multicolumn{2}{|c|}{ Model including fiscal decentralization } \\
\hline & Coefficient & $t$-statistic & Coefficient & $t$-statistic \\
\hline GREENTAX & $-0.01999 * *$ & -2.57 & & \\
\hline REGand*GREENTAX & & & $-0.01884 *$ & -1.68 \\
\hline REGmad*GREENTAX & & & 0.00295 & 0.43 \\
\hline BUSINV & $-0.55422 * *$ & -8.27 & $-0.56135 * *$ & -8.01 \\
\hline PCINCOME & -1.08856 & -0.46 & -2.79812 & -0.96 \\
\hline PCINCOME 2 & $-2.07143 * *$ & -5.97 & $-2.39422 * *$ & -6.53 \\
\hline POPSTUDIES & 0.00575 & 0.05 & -0.00673 & -0.06 \\
\hline POPAGE & $10.57117 * *$ & 3.79 & $10.31038 * *$ & 3.68 \\
\hline$V A B I N D$ & $4.09452 *$ & 2.96 & $4.73357 * *$ & 3.44 \\
\hline$V A B C O N S T$ & $4.04221 *$ & 2.85 & $3.78927 * *$ & 2.64 \\
\hline$V A B E N E R G$ & $-0.80373 *$ & -2.58 & $-0.73474 *$ & -2.14 \\
\hline$R^{2}$ & \multicolumn{2}{|c|}{0.985} & \multicolumn{2}{|c|}{0.986} \\
\hline LM heterogeneity test & \multicolumn{2}{|c|}{16.68} & \multicolumn{2}{|c|}{13.78} \\
\hline Durbin-Watson statistic & \multicolumn{2}{|c|}{2.24} & \multicolumn{2}{|c|}{2.27} \\
\hline F-statistic & \multicolumn{2}{|c|}{62.62} & \multicolumn{2}{|c|}{59.52} \\
\hline Hausman endogeneity test & \multicolumn{2}{|c|}{2.06} & \multicolumn{2}{|c|}{2.82} \\
\hline
\end{tabular}

** Significantly different from 0 with a confidence level of 99 percent with a two-tailed test 